\title{
Effects of Exogenous Progesterone on Fetal Nuchal Translucency Measured By 2d Ultrasonography
}

\author{
By
Mohammad Gomaa Ali Abd Al-Jawad, Fawzi Ahmed Abd El-Aziz and Wael Soliman Taha

Department of Obstetrics and Gynecology, Faculty of Medicine, Al Azhar University

Corresponding author: Mohammad Gomaa Ali Abd Al-Jawad,

E-mail: mohammedgomaa793@gmail.com

\begin{abstract}
Background: Progesterone is an essential hormone for the continuation of pregnancy and is prescribed in $13-40 \%$ of women with threatened miscarriage, according to the literature. Progesterone shows these effects by releasing certain anti-abortive cytokines, modulation of the maternal immune system (immunological tolerance of the fetus), and with relaxation of uterine muscles.
\end{abstract}

Objective: To evaluate the thickness of fetal nuchal translucency between 11-14 weeks' gestation among women receiving exogenous progesterone and to compare these findings with controls to determine the effect of progesterone on NT.

Patients and Methods: This is a prospective case control study upon pregnant women presented to the obstetric outpatient clinic and fetal medicine unit at Al-Hussien hospital in their first trimester during the period from March 2019 till the end of March 2020. One handred women were included in this study, and they were divided into two equal groups: group A and group B control group. To evaluate the thickness of fetal nuchal translucency between 11-14 weeks' gestation among women receiving exogenous progesterone and to compare these findings with controls to determine the effect of progesterone on NT.

Results: There was a statistical significant correlation between nuchal translucency (NT) among cases and control group as mean thickness in cases was $1.5 \mathrm{~cm}$ ranging from $1 \mathrm{~cm}$ to $2 \mathrm{~cm}$ with \pm 0.4 standard deviation, while in control group the mean thickness was $1.2 \mathrm{~cm}$ ranging from $0.9 \mathrm{~cm}$ to $1.8 \mathrm{~cm}$ and \pm 0.2 standard deviation and $\mathrm{p}$ value 0.001 which correlate statistical significance. Thus exogenous progesterone significantly increases NT thickness when compared with controls. However, none of cases nor control had babies with pathological thickness in the nuchal translucency. Thus none of the studied groups underwent further assessment using biochemical markers in the form of $\beta$ HCG and PAPP-A nor amniocentesis. The mean NT was s significantly higher in the studied cases taking progesterone. However, this increase was still within the normal range of NT and did not affect the risk of aneuploidy.

Conclusion: The mean nuchal translucency significantly increased in cases taking progesterone therapy in the first trimester. However, this increase is still within the normal range of nuchal translucency. Although nuchal translucency was found to be associated to progesterone intake, the dose of which, duration and indication of intake didn't statistically relate to the thickness of nuchal translucency.

Keywords: Nuchal translucency, prenatal screening tests, progesterone therapy, Down syndrome.

\section{INTRODUCTION}

Nuchal translucency (NT) is a transient subcutaneous collection of fluids behind the fetal neck seen ultrasonographically at
11-14 weeks' gestation, and is recognized as a sensitive marker for Down syndrome (Guraya, 2013). 
Despite its important role in the first trimester of pregnancy for Down syndrome screening, the use of NT measurement is still considered controversial particularly due to the verification bias, which is likely to cause overestimation of the detection rate. Furthermore, it is well known that increased NT is also present in euploid fetuses (Alldred et al., 2017).

Many pathophysiological theories have been put forward to explain this increase, so that described fluid retention after exposure to many environmental factors early in pregnancy (Iuculano et al., 2019).

The presence of progesterone receptors has been demonstrated in the placenta and in the feto-placental vascular tree, especially in the muscular layer of the vessel working through nuclear receptor proteins (He et al., 2016).

It has been demonstrated that progesterone could cause both rapid dosedependent relaxation of the placental vascular smooth muscle (Pang and Thomas, 2018), and the proliferation of cultured human vascular smooth muscle cells of the umbilical vein (Lastra et al., 2019).

With the increased use of progesterone, two meta-analyses evaluated its use in the first trimester of pregnancy for both prevention of miscarriage and for treating threatened miscarriage in a low-risk population and stated that it does not modify the outcome (Wahabi et al., 2011).

More meta-analysis confirmed these data suggesting a possible but still not well-proven effect in patients with a history of recurrent abortion. Low clinical evidence continues to support the use of progesterone in the first trimester even to treat threatened miscarriage (Haas and Ramsey, 2013).

Thus, the only robust clinical evidence for the use of progesterone is for assisted reproductive technology (ART) pregnancy (Van der Linden et al., 2011), and for women at high risk for preterm birth (Dodd et al., 2013).

It was speculated that the use of exogenous progesterone in the first trimester of pregnancy could lead to abnormal blood flow patterns that may affect both the expression of the growth factors required for the normal development of the fetus and the deregulation of fetal blood pressure (Giorlandino et al., 2015).

In the assessment of fetal NT, the ultrasound machine should be of high resolution with a video-loop function and calipers that provide measurements to 1 decimal point. Fetal NT can be measured successfully by transabdominal ultrasound examination in approximately $95 \%$ of cases (Maymon and Herman, 2018).

The present work aimed to evaluate the thickness of fetal nuchal translucency between 11-14 weeks' gestation among women receiving exogenous progesterone and, to compare these findings with controls to determine the effect of progesterone on NT.

\section{PATIENTS AND METHODS}

This was a prospective case control study upon pregnant women presented to the Obstetric Outpatient Clinic and Fetal Medicine Unit in Al-Hussien Hospital in their first trimester during the period from March 2019 till the end of March 2020. 
One handred women were included in our study, and divided into two equal groups: Group A: Women receiving exogenous progesterone (cases), and Group B: Women not receiving exogenous progesterone (control group).

Inclusion criteria: Age between 18-39 years, gestational age between 11 and 14 weeks, and women receiving progesterone treatment at a dose more than or equal to $200 \mathrm{mg} /$ day for a period more than or equal to 1 week.

Exclusion criteria: Body mass index $(\mathrm{BMI})>35 \mathrm{~kg} / \mathrm{m} 2$, concomitant medications other than progesterone, patients who have no evidence of cardiac activity, patients how have major fetal abnormalities and/or placental abnormalities.

Primary outcomes: To evaluate the effects of exogenous progesterone on fetal nuchal translucency thickness compared to controls.
Secondary outcome parameters: To identify the correlation between progesterone dose and NT variation.

\section{Statistical analysis:}

Data were statistically described in terms of mean \pm standard deviation $( \pm$ SD) or frequencies (number of cases) and percentages when appropriate. Mann Whitney test was used to compare the mean NT $(\mathrm{mm})$ between the two studied groups, Chi square (X2) test was performed. Correlation analysis was used to correlate the studied parameters in group A, Exact test was used instead when the expected frequency is less than 5. p values less than 0.05 was considered statistically significant. All statistical calculations were done using computer program SPSS (Statistical Package for the Social Science; SPSS Inc., Chicago, IL, USA) release 15 for Microsoft Windows (2016).

\section{RESULTS}

Age from 19 to 24 years represented $15 \%$ from total: $5 \%$ in group A, and $20 \%$ in group B. The percentage of the age group from 25 to 29 years was $43 \%$ from total: $50 \%$ in group A and $36 \%$ in group B. Women aged from 30 to 34 years represented 20\% from total: $20 \%$ in group $\mathrm{A}$ and $20 \%$ in group B. Women aged $\geq 35$ was $22 \%$ from total: $20 \%$ in group A and $22 \%$ in group B.

Among 24 primigravida included in the study, 15 women were in group A and 9 in group B. Para 1 represented also 26 women: 11 in group A and 15 in group B. Para 2 women were 28, in group A 17 and in group B 11. Para 3 included in the study were 15 women: 7 in group A and 8 in group B. Another 7 women with high parity (para 4\&5) were only found in group B.

Only 14 women were included during the 11th week gestation: 9 in group A and 5 in group B. Also, 14 women in the 14th week: 8 in group A and 6 in group B. Most of women included were in the $12^{\text {th }}$ and $13^{\text {th }}$ week. In the $12^{\text {th }}$ week, 37 women were included: 17 in group $\mathrm{A}$ and 20 in group $\mathrm{B}$, while in $13^{\text {th }}$ week, a total of 35 women: 16 in group $A$ and 19 in group B (Table 1). 
Table (1): Distribution age, parity and gestational age among studied groups

\begin{tabular}{|c|c|c|c|c|c|c|c|}
\hline \multirow{3}{*}{$\begin{array}{l}\text { Groups } \\
\text { Parameters } \\
\text { Age group: } \\
\text { 19-24 years }\end{array}$} & \multirow{2}{*}{\multicolumn{2}{|c|}{$\begin{array}{l}\text { Group A } \\
\text { No. }=\mathbf{5 0}\end{array}$}} & \multirow{2}{*}{\multicolumn{2}{|c|}{$\begin{array}{l}\text { Group B } \\
\text { No. }=\mathbf{5 0}\end{array}$}} & \multirow{2}{*}{\multicolumn{2}{|c|}{$\begin{array}{c}\text { Total } \\
\text { No. }=100\end{array}$}} & \multirow{2}{*}{$\begin{array}{c}\mathbf{P} \\
\text { value }\end{array}$} \\
\hline & & & & & & & \\
\hline & 5 & $10.0 \%$ & 10 & $20.0 \%$ & 15 & $5.0 \%$ & \multirow{4}{*}{0.393} \\
\hline 25-29 years & 25 & $50.0 \%$ & 18 & $36.0 \%$ & 43 & $43.0 \%$ & \\
\hline 30-34 years & 10 & $20.0 \%$ & 10 & $20.0 \%$ & 20 & $20.0 \%$ & \\
\hline 35-39 years & 10 & $20.0 \%$ & 12 & $24.0 \%$ & 22 & $22.0 \%$ & \\
\hline $\begin{array}{l}\text { PARITY: } \\
\text { Primigraavida }\end{array}$ & 15 & $30.0 \%$ & 9 & $18.0 \%$ & 24 & $24.0 \%$ & \multirow{5}{*}{$\mathbf{0 . 0 3 3}$} \\
\hline Para 1 & 11 & $22.0 \%$ & 15 & $30.0 \%$ & 26 & $26.0 \%$ & \\
\hline Para 2 & 17 & $28.0 \%$ & 11 & $22.0 \%$ & 28 & $28.0 \%$ & \\
\hline Para 3 & 7 & $14.0 \%$ & 8 & $16.0 \%$ & 15 & $15.0 \%$ & \\
\hline Para 4\&5 & 0 & $0.0 \%$ & 7 & $14.0 \%$ & 7 & $7.0 \%$ & \\
\hline $\begin{array}{l}\text { Gestational } \\
\text { age: }\end{array}$ & 9 & $18.0 \%$ & 5 & $10.0 \%$ & 14 & $14.0 \%$ & \multirow{5}{*}{0.587} \\
\hline $12^{\text {th }}$ week & 17 & $34.0 \%$ & 20 & $40.0 \%$ & 37 & $37.0 \%$ & \\
\hline $13^{\text {th }}$ week & 16 & $32.0 \%$ & 19 & $38.0 \%$ & 35 & $35.0 \%$ & \\
\hline $14^{\text {th }}$ week & 8 & $16.0 \%$ & 6 & $12.0 \%$ & 14 & $14.0 \%$ & \\
\hline Total & 50 & $50 \%$ & 50 & $50 \%$ & 100 & $100 \%$ & \\
\hline
\end{tabular}

Analysis of the group A as regarding indication of progesterone intake showed that among 50 cases: 37 women took progesterone empirically with no clinical indication. However, 8 cases took progesterone due to history of recurrent abortion, and 5 cases took progesterone due to occurrence of threatened abortion in the current pregnancy. The dose of progesterone varied from $200 \mathrm{mg} /$ day to $600 \mathrm{mg} /$ day with mean 340 and standard deviation \pm 142.8 . The duration of progesterone intake ranged from one week to 6 weeks with a mean of 3 weeks and standard deviation \pm 1.0 . By analyzing other factors that may contribute to nuchal translucency among group A in the studied group, it was found that crown rump length (CRL), age and mode of previous delivery were significantly correlated statistically with nuchal translucency in group A ( $p$ value was $0.02,0.011$ and 0.004 respectively). In the same context, parity, gestational age (GA), history of abortion and mode of conception weren't statistically correlated to nuchal translucency. Although nuchal translucency was found to be correlated to progesterone intake, the dose of which, duration and indication of intake didn't statistically relate to the thickness of nuchal translucency (Table 2). 
Table (2): Indication of progesterone intake, dosage, and period of progesterone therapy in the studied group. Analysis factors associated with nuchal thickness in Group A

\begin{tabular}{|l|c|c|}
\hline \multirow{2}{*}{ Parameters } & Cases & N= 50 \\
\hline \multirow{3}{*}{ Indications of Progesterone } & Empirical & $37(74.0 \%)$ \\
\cline { 2 - 3 } & Recurrent & $8(16.0 \%)$ \\
\cline { 2 - 3 } & Threatened & $5(10.0 \%)$ \\
\hline \multirow{2}{*}{ Dose (mg) } & Mean \pm SD & $340 \pm 142.8$ \\
\cline { 2 - 3 } & Range & $200-600$ \\
\hline $\begin{array}{c}\text { Period of progesterone } \\
\text { therapy (weeks) }\end{array}$ & Mean \pm SD & $3.0 \pm 1.0$ \\
\hline \multirow{2}{*}{ Cases } & Range & $01-06$ \\
\hline Parameters & $\begin{array}{c}\text { Confidence Intervals (r) } \\
(\mathbf{9 5 \%} \text { CI) }\end{array}$ & \multirow{2}{*}{ P value } \\
\hline CRL & $0.38(0.1-0.6)$ & $\mathbf{0 . 0 2}$ \\
\hline Age & $0.39(0.09-0.6)$ & $\mathbf{0 . 0 1 1}$ \\
\hline Garity & $0.19(-0.1-0.5)$ & 0.239 \\
\hline Modtational age of previous delivery & $-0.07(-0.4-0.2)$ & 0.656 \\
\hline Mode of conception & $-0.44(-0.7--0.2)$ & $\mathbf{0 . 0 0 4}$ \\
\hline History of abortion & $0.15(-0.2-0.4)$ & 0.363 \\
\hline Dose of progesterone & $0.10(-0.2-0.4)$ & 0.526 \\
\hline Period of therapy & $0.05(-0.3-0.3)$ & 0.761 \\
\hline Indication of progesterone & $-0.03(-0.3-0.3)$ & 0.882 \\
\hline
\end{tabular}

There was a statistical significant correlation between nuchal translucency (NT) among group A and group B as mean thickness in group A was $1.5 \mathrm{~mm}$ ranging from $1 \mathrm{~mm}$ to $2 \mathrm{~mm}$ with \pm 0.4 standard deviation, while in group B the mean thickness was $1.2 \mathrm{~mm}$ ranging from
$0.9 \mathrm{~mm}$ to $1.8 \mathrm{~mm}$ and \pm 0.2 standard deviation and $\mathrm{p}$ value 0.001 with statistical significance. However; none of group A nor group B had fetuses with pathological thickness in the nuchal translucency (Table 3).

Table (3): Comparison between nuchal translucency (NT) among studied groups

\begin{tabular}{|c|c|c|c|}
\hline \multirow{2}{*}{$\begin{array}{l}\text { GT (mm) } \\
\text { NT }\end{array}$} & Group A & Group B & \multirow[b]{2}{*}{ P-value• } \\
\hline & No. $=50$ & No. $=50$ & \\
\hline Mean \pm SD & $1.5 \pm 0.4$ & $1.2 \pm 0.2$ & \multirow{2}{*}{0.001} \\
\hline Range & $1-2$ & $0.9-1.8$ & \\
\hline
\end{tabular}

\section{DISCUSSION}

There was a statistical significant difference between nuchal translucency (NT) among cases and control group. Exogenous progesterone significantly increased NT thickness when compared with controls. However; none of cases nor control had babies with pathological thickness in the nuchal translucency and none of the studied groups underwent further assessment using biochemical markers in the form of $\beta$ HCG and PAPPA nor amniocentesis.

The effect of first-trimester progesterone use on NT measurement was investigated in this study, where NT 
values were significantly higher in the progesterone group than in the nonprogesterone group (Kalem et al., 2018).

The presence of progesterone receptors in the human fetoplacental vessels is a well-described condition and its vasoactive actions are well documented in other tissues (Monni et al., 2016).

A genomic and nongenomic action of steroid hormones via nuclear and progesterone receptors are important for an adequate fetoplacental blood flow, which is necessary for regular fetal development during pregnancy (Kumar, 2016).

Progesterone activity predominantly works through nuclear receptor proteins (A and B form). These receptors acted as transcriptional factors that regulate specific gene expression. It has been demonstrated that progesterone could cause rapid dose-dependent relaxation of the placental vascular smooth muscle from chorionic arteries and veins by an endothelium-independent mechanism. This rapid effect may be mediated by a receptor localized on the membranes of the smooth muscle cells (He et al., 2016). Progesterone inhibits the proliferation of cultured human vascular smooth muscle cells of the umbilical vein induced by mitogenic agents such as endothelin 1 (Pang and Thomas, 2017).

Moreover, progesterone receptors were also found in fetuses between 11-21 weeks of gestation in all the tissues examined and a part of exogenous progesterone is picked up in fetal circulation because it enters through the same metabolic pathways as endogenous progesterone. In the last decade, the use of exogenous progesterone has increased and the Food and Drug Administration has expressed its concerns regarding its effectiveness and safety, placing it in category B warning (Connolly and Eddleman, 2016). The use of progesterone during the first trimester of pregnancy should be reserved to cases of ART pregnancies where a luteal phase is insufficient and the maternal plasma progesterone is low (van der Linden et al., 2011) or in cases of women at risk for preterm birth (Dodd et al., 2013).

In fact, 2 meta analyses have stated that progesterone either in the prevention or treatment of miscarriages does not modify the outcome of pregnancy, concluding that information about potential harms to the mother or child, or both, with the use of progestogens is lacking (Wahabi et al., 2011).

Many theories have been put forward including cardiac dysfunction, congestion of the venous system in the neck and in the head, and abnormal lymphatic drainage due to delayed development (Westerway and Basseal, 2017).

Giorlandino et al. (2015) were the first to demonstrate the relation between nuchal thickness and the intake of progesterone. They found that exogenous progesterone increased the mean NT by $0.08 \mathrm{~mm}$ with a statistical significance and they thought that the possible action of progesterone on the placental vascular tree could determine a difficulty of the blood in flowing through the heart and this increase in cardiac work might be responsible for fluid retention in the head and neck. The increase in cardiac work, although transitory, would affects the preloading mechanism (central venous flow), overloading it. This might be 
responsible for fluid retention in the head and neck. They showed that exogenous progesterone therapy affects fetal NT thickness regardless of progesterone content, dosage, and route of administration.

Keçecioğlu et al. (2016) included women receiving progesterone for only threatened abortion and found that the mean NT thickness was significantly higher in the study group and there was a positive correlation between NT and treatment duration. They concluded that oral progesterone therapy may increase NT depending on treatment duration without causing abnormal prenatal screening test results.

Shiefa et al. (2013) and Serra et al. (2015) suggested that the assumption of Giorlandino et al. (2015) was not supported by their data.

Bellver et al. (2013) conducted a study to identify the additive factors that may affect serum PAPP-A in ART patients and they found that NT was not affected. However, Güzel et al. (2019) conducted a study on nuchal translucency in pregnancies conceived after assisted reproduction technology and found that increased nuchal translucency in assisted reproduction pregnancies would result in a false positive rate higher than expected. However, this study didn't relate thickened nuchal translucency to the high dose of progesterone given to support luteal phase in ART.

The mean NT was statistically significant higher in the studied cases taking progesterone. However, this increase still within the normal range of NT and doesn't affect the risk of aneuploidy.

\section{CONCLUSION}

The mean nuchal translucency significantly increased in cases taking progesterone therapy in the first trimester. Which is still within the normal range of nuchal translucency. Although nuchal translucency was found to be associated to progesterone intake, the dose of which duration, and indication of intake did not statistically relate to the thickness of nuchal translucency.

\section{REFERENCES}

1. Alldred SK, Takwoingi Y, Guo B, Pennant M, Deeks JJ, Neilson JP and Alfirevic Z (2017): First trimester ultrasound tests alone or in combination with first trimester serum tests for Down's syndrome screening. Cochrane Database of Systematic Reviews, (3): 16-24.

2. Bellver J, Casanova C, Garrido N, Lara C, Remohí J, Pellicer A and Serra V (2013): Additive effect of factors related to assisted conception on the reduction of maternal serum pregnancy-associated plasma protein A concentrations and the increased false-positive rates in first-trimester Down syndrome screening. Fertility and Sterility, 100(5):131420.

3. Connolly KA and Eddleman KA (2016): Amniocentesis: A contemporary review. World Journal of Obstetrics and Gynecology, 5(1):58-65.

4. Dodd JM, Jones L, Flenady V, Cincotta $R$ and Crowther CA (2013): Prenatal administration of progesterone for preventing preterm birth in women considered to be at risk of preterm birth. Cochrane Database Syst Rev., 7: 4947-53.

5. Giorlandino $\mathbf{C}$, Cignini $\mathbf{P}$, Padula $\mathbf{F}$, Giannarelli D, d'Emidio L, Aloisi A, Plotti F and Angioli R (2015): Effects of exogenous progesterone on fetal nuchal translucency: an observational prospective study. American Journal of Obstetrics and Gynecology, 212(3):335-341. 
6. Guraya SS (2013): The associations of nuchal translucency and fetal abnormalities, significance and implications. Journal of Clinical and Diagnostic Research, 7(5):93642.

7. Güzel Y, Türkgeldi E, Yağmur H, Salar Z, Balaban B, Urman B and Öktem Ö (2019): Spontaneous and in vitro fertilization pregnancies have comparable first trimester screening profiles for Down syndrome. Journal of the Turkish German Gynecological Association, 20(2):97-101.

8. Haas DM and Ramsey PS (2013): Progestogen for preventing miscarriage. Cochrane Database Syst Rev., 10: 3511-16.

9. He Y, Gao Q, Han B, Zhu X, Zhu D, Tao J, Chen $J$ and $X u Z$ (2016): Progesterone suppressed vasoconstriction in human umbilical vein via reducing calcium entry. Steroids, 108:118-25.

10. Iuculano A, Murgia F, Peddes C, Santoru ML, Tronci L, Deiana M, Balsamo A, Euser A, Atzori L and Monni G (2019): Metabolic characterization of amniotic fluids of fetuses with enlarged nuchal translucency. Journal of Perinatal Medicine, 47(3):311-8.

11. Kalem MN, Kalem Z, Bakırarar B, Ergün $A$ and Gürgan $T$ (2018): The effect of progesterone use in the first trimester on fetal nuchal translucency. Journal of the Turkish German Gynecological Association, 19(1):2936.

12. Keçecioğlu M, Tokmak A, Keçecioğlu TS, Akselim B, Karakaya BK and Taşçı Y (2016): Does progesterone therapy increase nuchal translucency in women with threatened miscarriage? Ginekologia Polska, 87(5):390-4.

13. Kumar B (2016): Ultrasound-guided diagnostic procedures, Fetal Medicine. Cambridge University Press, 7(27): 337-344.

14. Lastra G, Harbuz-Miller I, Sowers JR and Manrique CM (2019): Estrogen receptor signaling and cardiovascular function. In: Sex Differences in Cardiovascular Physiology and Pathophysiology. Academic Press, Pp. 13-22.
15. Maymon $R$ and Herman A (2018): Nuchal Translucency Measurement. Prenatal Assessment of Multiple Pregnancy, 47: 8-13.

16. Monni G, Pagani G, Stagnati V, Iuculano A and Ibba RM (2016): How to perform transabdominal chorionic villus sampling: a practical guideline. The Journal of MaternalFetal \& Neonatal Medicine, 29(9):1499-505.

17. Pang $Y$ and Thomas $P$ (2017): Additive effects of low concentrations of estradiol-17 $\beta$ and progesterone on nitric oxide production by human vascular endothelial cells through shared signaling pathways. The Journal of Steroid Biochemistry and Molecular Biology, 165:258-67.

18. Pang $Y$ and Thomas $P$ (2018): Progesterone induces relaxation of human umbilical cord vascular smooth muscle cells through $\mathrm{mPR} \alpha$ (PAQR7). Molecular and Cellular Endocrinology, 474:20-34.

19. Serra V, Bellver J and Garrido N (2015): Doubtful association between progesterone therapy and fetal nuchal translucency. American Journal of Obstetrics \& Gynecology, 5: 437.

20. Shiefa S, Amargandhi M, Bhupendra J, Moulali S and Kristine T (2013): First trimester maternal serum screening using biochemical markers PAPP-A and free $\beta$-hCG for down syndrome, patau syndrome and edward syndrome. Indian Journal of Clinical Biochemistry, 28(1):3-12.

21. van der Linden $M$, Buckingham $K$, Farquhar C, Kremer JA and Metwally M (2011): Luteal phase support for assisted reproduction cycles. Cochrane Database Syst Rev., 10: 9154-9.

22. Wahabi HA, Abed Althagafi NF, Elawad M and Al Zeidan RA (2011): Progestogen for treating threatened miscarriage. Cochrane Database Syst Rev., 3: 5943-8.

23. Westerway SC and Basseal JM (2017): Advancing infection control in Australasian medical ultrasound practice. Australasian Journal of Ultrasound in Medicine, 20(1):269. 


\section{تأثيرات البروجستروز الخارجي علي الشفافية القفوية للجنين مقاسة بسونار ثنائي الأبعاد}

محمد جمعة علي عبد الجواد، فوزي احمد عبد العزيز، وائل سليمان طه

قسم النساء والتوليل، كلية الطب، جامعة الأزهر

E-mail: mohammedgomaa793@gmail.com

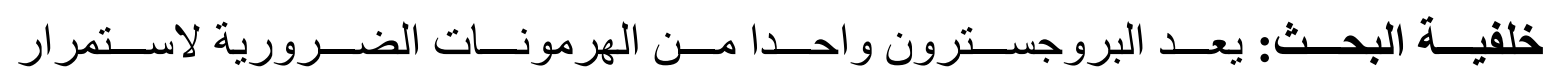

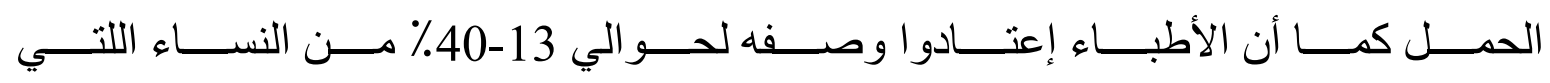

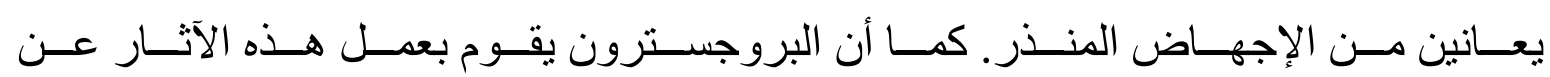

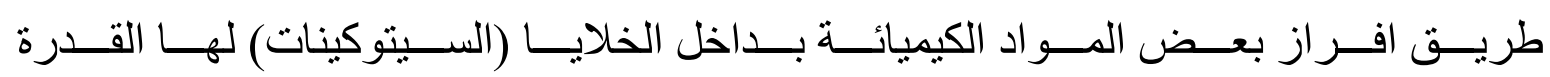

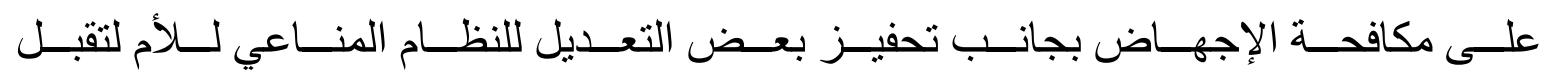

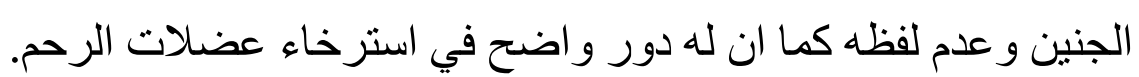

الهــــف مـــن البحـــث: دراســـة تـــأثير هرمـــون البروجســـترون الخـــارجي علــى الثفافية القفوية للجنين في الفترة من 11 إلي 14 اسبوع من الحمل.

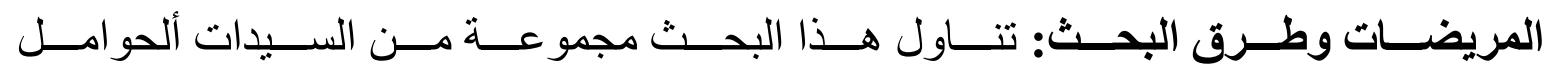

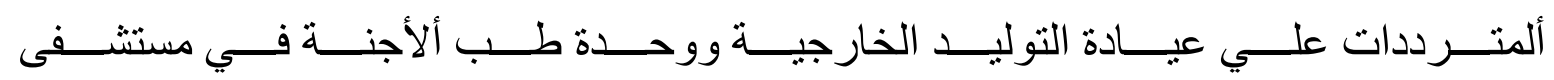

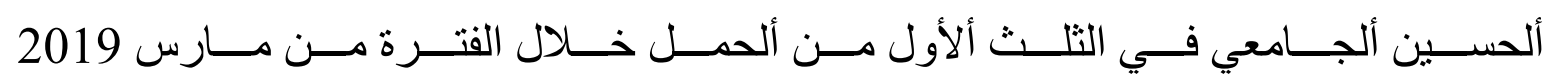

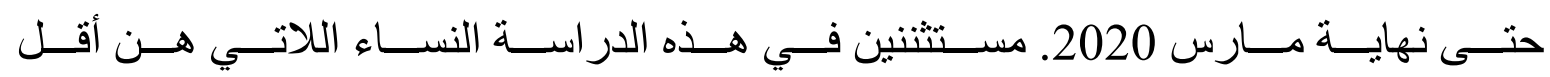

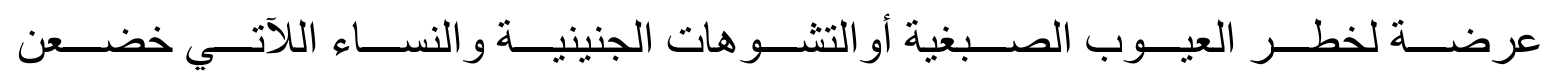

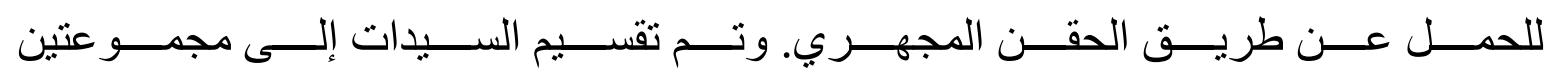

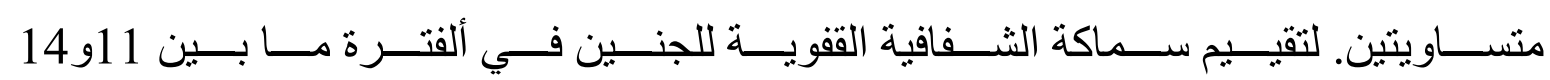

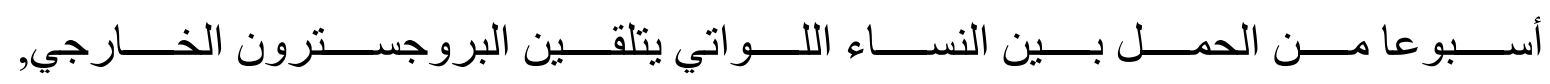

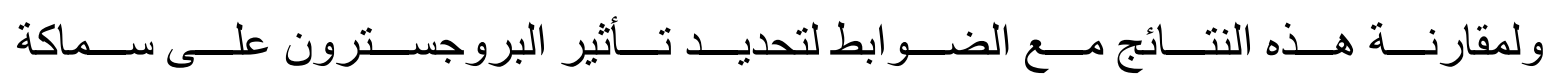
الثفافية القفوية للجنين. 
نتــائج البحــث: هنــاك علاقــة ذات دلالـــة إحصـــائية بــين الثــفافية القفويــة للحــالات

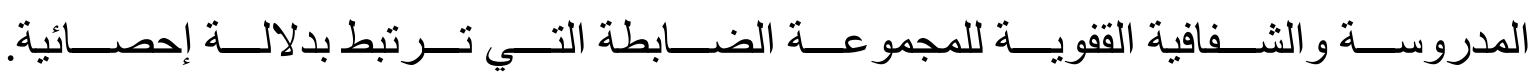

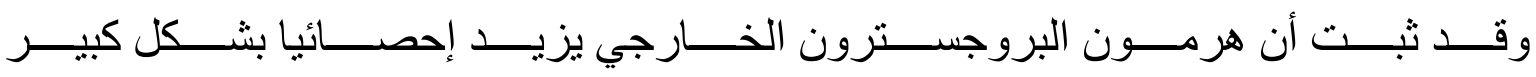
سماكة الثفافية القفوية بالمقارنة مع المجمو عة الضابطة.

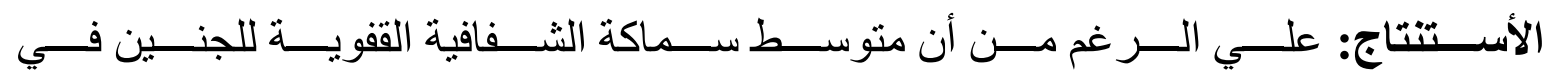

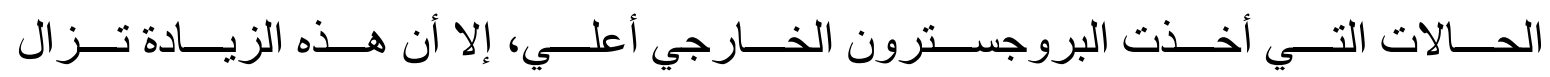

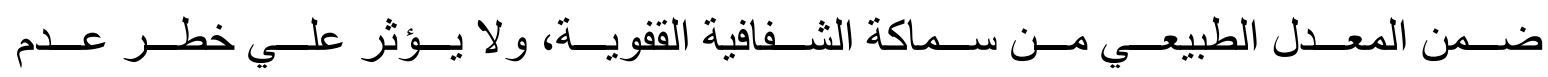
توازن الصبغيات.

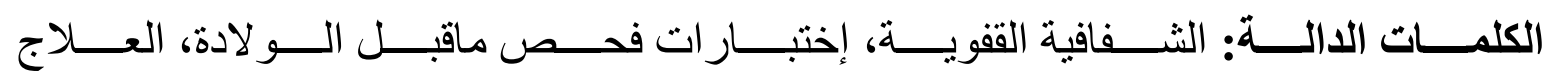
بالبروجسترون، متلازمة داون. 